\title{
A new chiral heterocyclic 1,1-enediamine as a precursor to piperidines
}

\author{
Raymond C. F. Jones* ${ }^{a}$ and Simon C. Hirst ${ }^{b}$ \\ ${ }^{a}$ Department of Chemistry, Loughborough University, Loughborough, Leics. LE11 3TU, UK \\ ${ }^{b}$ Department of Chemistry, University of Nottingham, University Park, Nottingham NG7 2RD, \\ $U K$ \\ E-mail: r.c.f.jones@lboro.ac.uk
}

\section{Dedicated to Professor Z.-T. Huang on his 75th anniversary}

(received 15 Mar 03; accepted 02 May 03; published on the web 11 May 03)

\begin{abstract}
A new chiral 4,5-dihydroimidazole enaminoester (a heterocyclic 1,1-enediamine) has been prepared as a potential precursor to piperidines, via 2,4,5-triphenyl-4,5-dihydroimidazole prepared from benzaldehyde and ammonia.
\end{abstract}

Keywords: Enaminoester, enediamine, dihydroimidazole, conjugate addition, tetrahydropyridine

\section{Introduction}

We have reported the application of enaminoester 1 (Figure 1), a 1,1-enediamine, ${ }^{1}$ in Michael additions with $\alpha, \beta$-unsaturated ketones. ${ }^{2}$ The conjugate addition products undergo a reductive cyclisation-elimination to afford tetrahydropyridines, which can be elaborated to piperidines (Scheme 1). ${ }^{3}$ In an effort to apply this route to optically active piperidines, we required a chiral enaminoester. We have reported elsewhere on the synthesis and reactions of the 4-phenyl derivative 2 in piperidine sytnthesis, ${ }^{4}$ and herein describe the rapid preparation and preliminary application of an alternative, the 4,5-diphenyl compound 3 from the $d$,l-diamine 4, itself easily prepared from benzaldehyde.

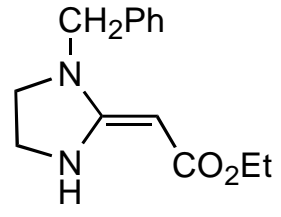

1

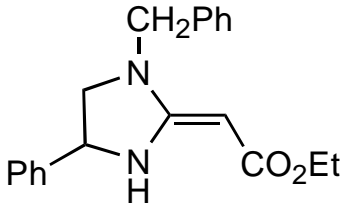

2<smiles>CCOC(=O)/C=C1/N[C@@H](c2ccccc2)[C@H](c2ccccc2)N1Cc1ccccc1</smiles>

3

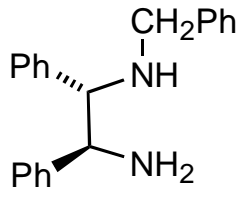

4

Figure 1. The heterocyclic enaminoesters (1,1-enediamines). 


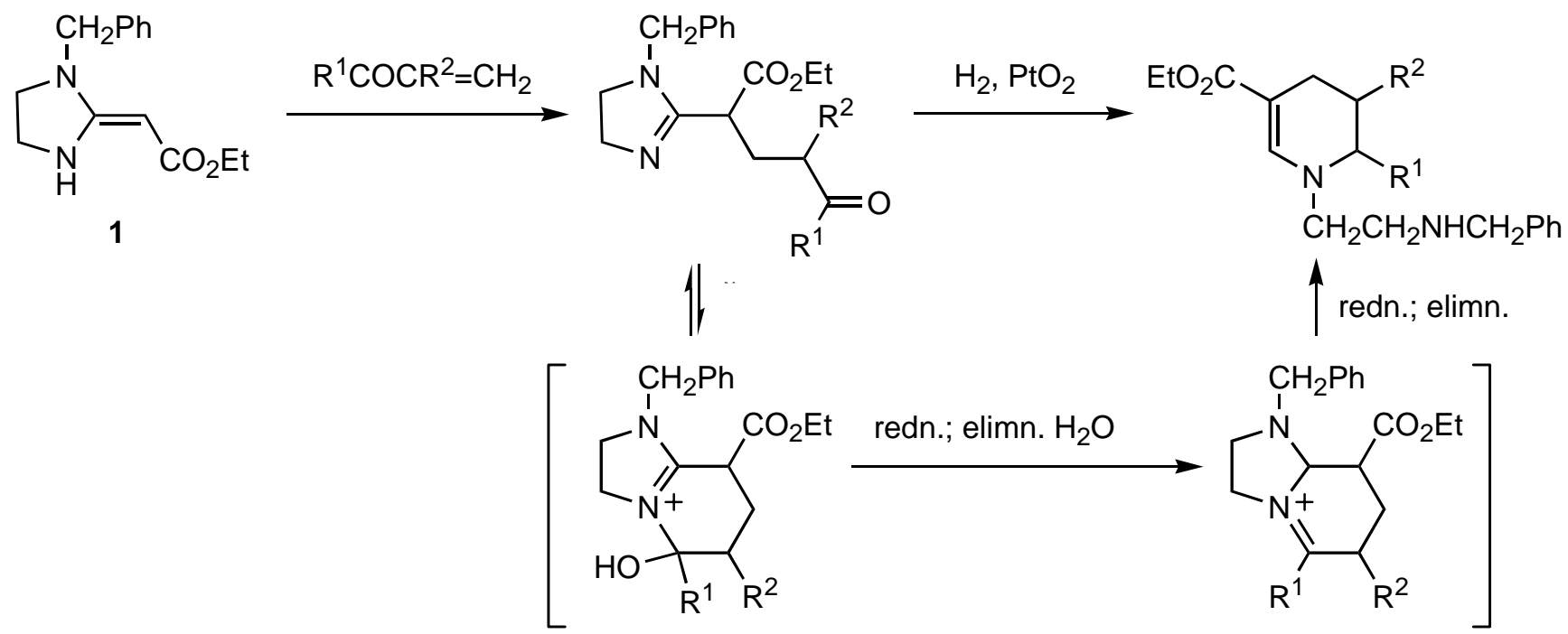

Scheme 1. The conjugate addition-reductive cyclisation-elimination strategy towards piperidines.

\section{Results and Discussion}

Synthesis of the required $d$,l-diamine 4 was accomplished according to Scheme 2. Treatment of benzaldehyde with a large excess of liquid ammonia for $16 \mathrm{~h}$ gave the bis-imine 5 in good yield (68\% after recrystallisation). ${ }^{5,6}$ This imine was originally wrongly ascribed the simple benzaldehyde imine structure. ${ }^{7}$ Thermal rearrangement in benzene (sealed tube, $130{ }^{\circ} \mathrm{C}$, 5h) afforded 2,4,5-triphenyl-2,5-dihydroimidazole 6 in $71 \%$ yield after recrystallisation. Isomerisation in base $\left(\mathrm{NaOH}, \mathrm{H}_{2} \mathrm{O}\right.$-diethylene glycol, $\left.150{ }^{\circ} \mathrm{C}, 45 \mathrm{~min}\right)$ led efficiently to the 4,5dihydroimidazole 7 as a single diastereoisomer (81\%), assigned as anti, based on its hydrolysis to a $d$,l-diamine. ${ }^{5}$

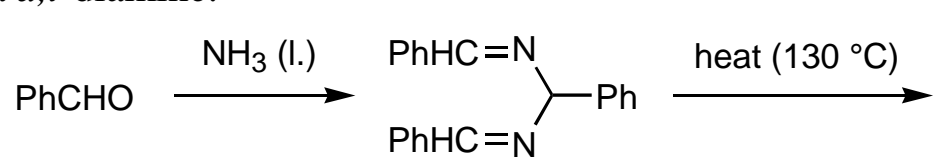

5<smiles>N[C@H](c1ccccc1)[C@H](NCc1ccccc1)c1ccccc1</smiles>

4<smiles>c1ccc(-c2nc(-c3ccccc3)c(-c3ccccc3)[nH]2)cc1</smiles>

6

$\mathrm{NaOH}, \mathrm{H}_{2} \mathrm{O}$, diethylene glycol, $150^{\circ} \mathrm{C}$<smiles>Pc1ccccc1</smiles>

7

Scheme 2. Preparation of the diamine 4. 
To prepare the mono-N-benzyl diamine 4 that we required, we initially attempted $\mathrm{N}$ benzylation of the dihydroimidazole 7 by our reported protocol ${ }^{8}$ (BuLi, THF, $0{ }^{\circ} \mathrm{C}$; then $\mathrm{PhCH}_{2} \mathrm{Br}$ ) as a prelude to complete hydrolysis, but only recovered unchanged starting material. Presumably the $\mathrm{N}$-atom in 7 is too sterically hindered; a control experiment with 2-phenyl-4,5dihydroimidazole successfully afforded 1-benzyl-2-phenyl-4,5-dihydroimidazole 8 in $72 \%$ yield under the same conditions (Figure 2). As an alternative, we recognised that the elements of the $\mathrm{N}$-benzyl substituent were already present in 7 and could be revealed by complete reduction of the amidine. ${ }^{9,10}$ Treatment of 1-unsubstituted dihydroimidazole 7 with $\mathrm{LiAlH}_{4}$ for a prolonged period (14 d, toluene, reflux), however, afforded no reduction. This has been attributed to formation of anionic $\mathrm{N}-\mathrm{Al}$ complexes and temporary $\mathrm{N}$-silylation proposed as a remedy. ${ }^{10}$ Thus silyl transfer by treatment with hexamethyldisilazane (reflux, $20 \mathrm{~h}$, cat. $\left.\mathrm{H}_{2} \mathrm{SO}_{4}\right)^{11}$ followed by reduction with lithium aluminium hydride or di-isobutylaluminium hydride (DIBAL-H) (xylene reflux) afforded, along with unchanged starting materials 7 , moderate yields of the desired $\mathrm{N}$ benzyl diamine 4 (36 or 37\%; 91 or 95\% based on recovered starting material).

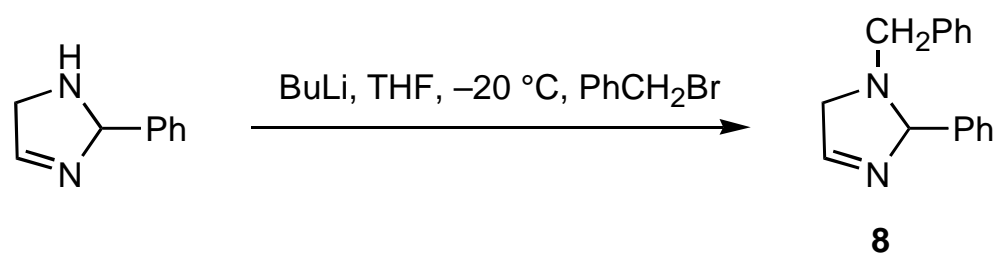

Figure 2. A model for N-1 alkylation.

The d,l-diamine 4 was condensed with ethyl ethoxycarbonylacetimidate hydrochloride (EtOH, reflux, $4 \mathrm{~h}$ ) to afford the tetrahydroimidazole 3 (Scheme 3) in good yield as a stable crystalline solid, ${ }^{12}$ a single diastereoisomer as revealed by ${ }^{1} \mathrm{H}$ NMR spectroscopy. The imidate itself was prepared from ethyl cyanoacetate $\left(\mathrm{EtOH}, \mathrm{AcCl}, 0{ }^{\circ} \mathrm{C}\right) .{ }^{13} \mathrm{In}$ a preliminary application of this chiral enaminoester, reaction with methyl vinyl ketone (MeCN reflux, $4 \mathrm{~h}$ ) led to the conjugate adduct 9 (92\%) as a 1:1 mixture of epimers at the labile C- $\alpha$ centre. Reductive cyclisation and eliminative ring cleavage ${ }^{3}$ with hydrogen over Adams catalyst $\left(1 \mathrm{~atm} \mathrm{H}_{2}, \mathrm{PtO}_{2}\right.$, $\mathrm{EtOH}, 2{ }^{\circ} \mathrm{C}$ ) gave the tetrahydropyridine 10 (94\%) as a single compound but demonstrating rotameric behaviour in solution. Clearly all the manipulations that we have reported earlier can now be employed on such tetrahydropyridines. ${ }^{3}$ 


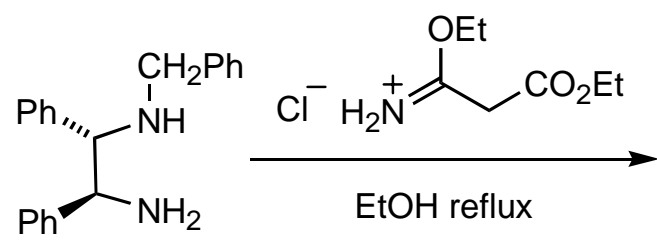

4<smiles>CCOC(=O)/C=C1\N[C@@H](P)[C@H](c2ccccc2)N1Cc1ccccc1</smiles>

3

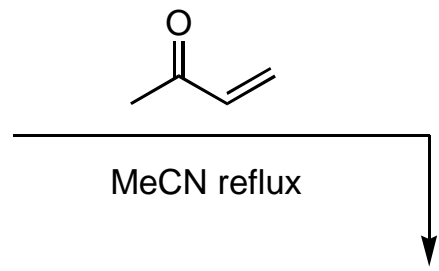

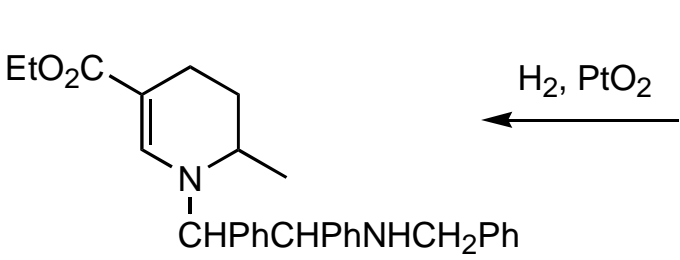

10

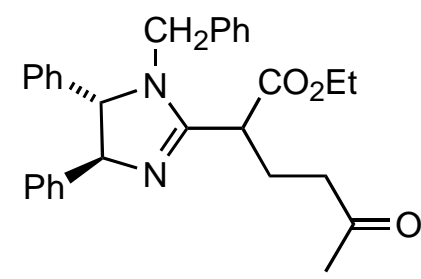

9

Scheme 3. Preparation and reaction of the enaminoester (enediamine) 3.

We have thus shown that chiral 4,5-diphenyl heterocyclic enediamine 3 can be readily prepared, and have shown its potential in piperidine assembly. Resolution of the diamine 4, as has been accomplished for the bis-primary amine, ${ }^{5,14}$ would allow both optically active enantiomers of enaminoester 3 to be accessed. This area awaits further development.

\section{Experimental Section}

General Procedures. Melting points were determined using a Kofler hot stage apparatus and are uncorrected. Infrared spectra were recorded on a Pye-Unicam SP3-100 or a Philips PU9706 spectrometer in chloroform unless otherwise stated. Nuclear magnetic resonance (NMR) spectra were recorded using the following instruments: ${ }^{1} \mathrm{H}$ spectra at $250 \mathrm{MHz}$ on a Bruker WM250 PFT or at $400 \mathrm{MHz}$ on a Bruker AM400 PFT; ${ }^{13} \mathrm{C}$ spectra on a Bruker FX90 at $22.5 \mathrm{MHz}$, a Bruker WM250 PFT at $62.5 \mathrm{MHz}$, or a Bruker AM400 PFT at $100 \mathrm{MHz}$ and multiplicites were determined using DEPT sequences. NMR Spectra were recorded for solutions in deuteriochloroform with tetramethylsilane as an internal standard unless otherwise stated. Chemical shifts are reported in parts per million (ppm) with the following abbreviations: $\mathrm{s}$ singlet, d - doublet, t - triplet, q - quartet and br - broad; coupling constants $(J)$ are quoted in Hz. Mass spectra were recorded on AEI MS902 or VG 7070E spectrometers using electron impact as the ionisation technique. Microanalytical data were obtained using a Perkin-Elmer 240B elemental analyser. Solvents were distilled prior to use; methanol was dried over magnesium turnings, diethyl ether over sodium, tetrahydrofurn distilled from potassium and acetonitrile from phosphorus pentoxide. Column chromatography was carried out at medium pressure using Merck Kieselgel 60 silica Art. 7729; flash column chromatography refers to chromatography on Merck silica Art. 9328. Thin layer chromatography (tlc) was carried out using silica G plates F254 (Merck 5554). Solvent extracts were dried $\left(\mathrm{MgSO}_{4}\right)$ for 10-30 min. before filtration and the removal of the solvent on a Büchi rotary evaporator. 
Benzaldehyde di(benzylimine)aminal (5). To benzaldehyde (10.00 g, $94 \mathrm{mmol})$ at $-40{ }^{\circ} \mathrm{C}$ was added liquid ammonia $\left(50 \mathrm{~cm}^{3}\right)$ and the vigorously stirred solution was allowed to warm to room temperature overnight. Final traces of ammonia were removed under reduced pressure and the residual pale yellow solid was recrystallised from cyclohexane to give the title compound as a white solid (6.38 g, 68\%), m.p. 98-99 ${ }^{\circ} \mathrm{C}$ (lit., ${ }^{5}$ m.p. 101-102 ${ }^{\circ} \mathrm{C}$ ); $v_{\max } / \mathrm{cm}^{-1}$ 3080, 3050, 2850, $1650(\mathrm{C}=\mathrm{N}), 1495,1455,1320,1050$, and 700 (Ph bend); $\delta_{\mathrm{H}} 6.00(1 \mathrm{H}, \mathrm{s}, \mathrm{PhCHN}), 7.45(9 \mathrm{H}, \mathrm{m}$, $\mathrm{ArH}), 7.90(4 \mathrm{H}, \mathrm{m}, \mathrm{ArH})$ and $8.60(2 \mathrm{H}, \mathrm{s}, 2 \times \mathrm{PhCH}=\mathrm{N}) ; \mathrm{m} / \mathrm{z} 195$ (20\%), $194\left(M^{+}-\mathrm{N}=\mathrm{CHPh}\right.$, 100), 165 (9), 116 (16), $91\left(\mathrm{C}_{7} \mathrm{H}_{7}^{+}, 21\right)$ and 89 (15).

2,4,5-Triphenyl-2,5-dihydroimidazole (6). Benzaldehyde di(benzylimine)aminal (5) (50.70 g, $0.48 \mathrm{~mol}$ ) was heated at $130{ }^{\circ} \mathrm{C}$ in benzene $\left(15 \mathrm{~cm}^{3}\right)$ for $5 \mathrm{~h}$. The resulting solid was slurried with hot cyclohexane $\left(10 \mathrm{~cm}^{3}\right)$, the mixture filtered and the collected solid recrystallised from toluene to give the title compound as a white crystalline solid (36.24 g, 71\%), m.p. 127-128 ${ }^{\circ} \mathrm{C}$ (lit., ${ }^{5}$ m.p. $128-129{ }^{\circ} \mathrm{C}$ ) (Found: $M^{+}$, 298.1497. $\mathrm{C}_{21} \mathrm{H}_{18} \mathrm{~N}_{2}$ requires $M, 298.1470$ ); $v_{\text {max }} / \mathrm{cm}^{-1} 3400$ $(\mathrm{NH}), 2940,2870,1620(\mathrm{C}=\mathrm{N}), 1600,1580,1460,1420,1290$, and 920; $\delta_{\mathrm{H}} 1.45(1 \mathrm{H}, \mathrm{s}, \mathrm{NH})$, 5.50 (2H, s, PhCHNCHPh), 7.15 (10H, m, ArH), 7.60 (3H, m, ArH), and 8.10 (2H, m, ArH); m/z 298 (M+1 13\%), 296 (16), 263 (4), 225 (4), 201 (8), 194 (M+N=CHPh, 23), 193 (92), 165 (23), 92 (66) and 91 (100).

2,4,5-Triphenyl-4,5-dihydroimidazole (7). 2,4,5-Triphenyl-2,5-dihydroimidazole 6 (17.00 g, $57 \mathrm{mmol}$ ) and sodium hydroxide (3.66 g, $92 \mathrm{mmol}$ ) were heated to $150{ }^{\circ} \mathrm{C}$ in aqueous diethylene glycol (42 $\mathrm{cm}^{3}$, diethylene glycol:water 5:1 v/v) for $45 \mathrm{~min}$. The resulting solid was dissolved by the addition of glacial acetic acid $\left(70 \mathrm{~cm}^{3}\right)$ and ethanol $\left(70 \mathrm{~cm}^{3}\right)$ and this solution was heated to reflux for $5 \mathrm{~min}$. The reaction mixture was basified with conc. aqueous ammonia and the resulting solid collected by filtration. Recrystallisation from ethanol gave the title compound as a white solid (13.84 g, 81\%), m.p. $199-200{ }^{\circ} \mathrm{C}$ (lit, $\left.{ }^{5} 198-201{ }^{\circ} \mathrm{C}\right) ; v_{\max } / \mathrm{cm}^{-1} 3420,2950,2880$, $1625(\mathrm{C}=\mathrm{N}), 1605,1580,1500,1460$, and 1280; $\delta_{\mathrm{H}} 4.80(2 \mathrm{H}, \mathrm{s}, 2 \mathrm{x} \mathrm{PhCHN}), 6.55(1 \mathrm{H}, \mathrm{s}, \mathrm{NH})$, $7.35(13 \mathrm{H}, \mathrm{m}, \mathrm{ArH})$ and $8.00(2 \mathrm{H}, \mathrm{m}, \mathrm{ArH})$.

\section{$N$-Benzyl-1,2-diphenyl-1,2-diaminoethane (4)}

Method A, LiAlH4 4 reduction. 2,4,5-Triphenyl-4,5-dihydroimidazole 7 (0.485 g, $1.6 \mathrm{mmol})$ in hexamethyldisilazane $\left(1.7 \mathrm{~cm}^{3}, 8.1 \mathrm{mmol}\right)$ with conc. sulphuric acid (1 drop) was heated at reflux under nitrogen for $20 \mathrm{~h}$. Excess hexamethyldisilazane was removed in vacuo and to the residual oil in THF $\left(10 \mathrm{~cm}^{3}\right)$ was cautiously added lithium aluminium hydride $(0.617 \mathrm{~g}, 16$ mmol). The mixture was heated at reflux for $4 \mathrm{~d}$ and the solvent removed by evaporation in a stream of nitrogen and replaced with xylene $\left(20 \mathrm{~cm}^{3}\right)$. After a further $2 \mathrm{~d}$ heating at reflux the reaction was quenched by the addition of ethyl acetate $\left(5 \mathrm{~cm}^{3}\right)$ and aqueous sodium hydroxide $\left(2 \mathrm{M} ; 5 \mathrm{~cm}^{3}\right)$. The reaction mixture was partitioned between water $\left(25 \mathrm{~cm}^{3}\right)$ and dichloromethane $\left(20 \mathrm{~cm}^{3}\right)$, and the aqueous phase further extracted with dichloromethane $\left(3 \times 20 \mathrm{~cm}^{3}\right)$. The extracts were dried, the solvent removed by evaporation and the residual oil purified by column chromatography $\left(\mathrm{CH}_{2} \mathrm{Cl}_{2}\right.$ :EtOH:conc. aq. $\left.\mathrm{NH}_{3} \quad 350: 8: 1 \mathrm{v} / \mathrm{v} / \mathrm{v}\right)$ to give recovered dihydroimidazole 7 (0.29 g), and the title compound 4 as a colourless oil $(0.178 \mathrm{~g}, 36 \%)$ that was used without further purification (Found: $M^{+}-\mathrm{PhCH}=\mathrm{NH}_{2}, 196.1126 . \mathrm{C}_{21} \mathrm{H}_{22} \mathrm{~N}_{2}$ requires $M-$ 
$\left.\mathrm{PhCH}=\mathrm{NH}_{2}, 196.1126\right) ; v_{\max } / \mathrm{cm}^{-1} 3380$ and $3320\left(\mathrm{NH}_{2}\right), 3060,2940,2860,1605\left(\mathrm{NH}_{2}\right.$ bend), 1490, 1455, and 1100; $\delta_{\mathrm{H}} 1.95\left(3 \mathrm{H}, \mathrm{s}, \mathrm{NH}\right.$ and $\mathrm{NH}_{2}$ ), 3.50 and 3.75 (each $1 \mathrm{H}, \mathrm{d}, \mathrm{J} 13 \mathrm{~Hz}$, $\mathrm{NCH}_{2} \mathrm{Ph}$ ), 3.80 and 4.05 (each $1 \mathrm{H}, \mathrm{d}, J 8 \mathrm{~Hz}, \mathrm{PhCHNH}$ ) and $7.30(15 \mathrm{H}, \mathrm{m}, \mathrm{ArH}) ; \delta_{\mathrm{C}} 51.5$ $\left(\mathrm{NCH}_{2} \mathrm{Ph}\right), 61.9$ and $68.9(\mathrm{CHNH}), 126.8,126.9,127.0,128.1$ and $128.3(\mathrm{ArCH}), 140.6,141.4$ and 143.6 (ArC); m/z $196\left(M^{+}-\mathrm{PhCH}=\mathrm{NH}_{2}, 9 \%\right), 149$ (33), 107 (29), $106\left(\mathrm{PhCH}=\mathrm{N}^{+} \mathrm{H}_{2}, 100\right), 91$ (45) and 79 (24).

Method B, DIBAL-H reduction. 2,4,5-Triphenyl-4,5-dihydroimidazole 7 (1.00 g, 3.4 mmol), hexamethyldisilazane $\left(2.7 \mathrm{~cm}^{3}, 17.0 \mathrm{mmol}\right)$, and conc. sulphuric acid (1 drop) were heated together at reflux for $27 \mathrm{~h}$. Removal of the excess hexamethyldisilazane under reduced pressure gave a colourless oil which was treated with di-isobutylaluminium hydride $\left(16.8 \mathrm{~cm}^{3}\right.$ of a $1 \mathrm{M}$ solution in hexanes, $16.8 \mathrm{mmol}$ ). The solvents were removed by evaporation under a flow of nitrogen and replaced with xylene $\left(10 \mathrm{~cm}^{3}\right)$. This solution was heated at reflux for $4 \mathrm{~d}$ and the reaction quenched with ethyl acetate $\left(12 \mathrm{~cm}^{3}\right)$, and water $\left(5 \mathrm{~cm}^{3}\right)$ (Caution: very exothermic!). The reaction mixture was partitioned between water $\left(50 \mathrm{~cm}^{3}\right)$ and dichloromethane $\left(50 \mathrm{~cm}^{3}\right)$ and the aqueous layer was further extracted with dichloromethane $\left(3 \times 50 \mathrm{~cm}^{3}\right)$. Drying of the extracts and removal of the solvents under reduced pressure gave a colourless oil which was purified by column chromatography $\left(\mathrm{CH}_{2} \mathrm{Cl}_{2}\right.$ :EtOH:conc. aq. $\mathrm{NH}_{3}$ 350:8:1 v/v/v) to give recovered dihydroimidazole 7 (0.60 g) and the title compound 4 as a colourless oil ( $0.38 \mathrm{~g}, 37 \%)$; all data were identical to material prepared using method A.

1-Benzyl-2-(ethoxycarbonylmethylene)-4,5-diphenyl-2,3,4,5-tetrahydroimidazole (3). To Nbenzyl-1,2-diphenyl-1,2-diaminoethane 4 (0.36 g, $1.2 \mathrm{mmol})$ in dry ethanol $\left(25 \mathrm{~cm}^{3}\right)$ was added ethyl 2-(ethoxycarbonyl)acetimidate hydrochloride $(0.23 \mathrm{~g}, 1.2 \mathrm{mmol})$ and the mixture was heated at reflux for $2.5 \mathrm{~h}$. The solvent was removed under reduced pressure and the residue was partitioned between aqueous sodium bicarbonate $(15 \mathrm{ml})$ and dichloromethane $(15 \mathrm{ml})$. The aqueous phase was further extracted with dichloromethane, the extracts dried, and the residual oil purified by column chromatography $\left(\mathrm{CH}_{2} \mathrm{Cl}_{2}\right.$ :EtOH:conc. aq. $\mathrm{NH}_{3}$ 300:8:1 v/v/v) to give the title compound 3 as a white crystalline solid (0.415 g, 88\%), m.p. 108-109 ${ }^{\circ} \mathrm{C}$ (Found: C, 78.39; $\mathrm{H}, 6.71 ; \mathrm{N}, 6.98 \%, M^{+}$, 398.1975. $\mathrm{C}_{26} \mathrm{H}_{26} \mathrm{~N}_{2} \mathrm{O}_{2}$ requires $\mathrm{C}, 78.36 ; \mathrm{H}, 6.58 ; \mathrm{N}, 7.03 \%$; $M$, 398.1994); $v_{\max } / \mathrm{cm}^{-1}(\mathrm{film}) 3350(\mathrm{NH}), 3080,3050,3000,2960,2850,1735(\mathrm{w}), 1655(\mathrm{C}=\mathrm{O})$, $1590(\mathrm{C}=\mathrm{C}), 1490,1100,785$, and 710 (Ph bend); $\lambda_{\max }(\mathrm{EtOH}) / \mathrm{nm} 274\left(\varepsilon / \mathrm{dm}^{3} \mathrm{~mol}^{-1} \mathrm{~cm}^{-1} 1.9 \mathrm{x}\right.$ $\left.10^{4}\right) ; \delta_{\mathrm{H}} 1.25\left(3 \mathrm{H}, \mathrm{t}, J 7 \mathrm{~Hz}, \mathrm{CH}_{3} \mathrm{CH}_{2} \mathrm{O}\right), 3.80(1 \mathrm{H}, \mathrm{d}, J 16 \mathrm{~Hz}, \mathrm{NCHHPh}), 4.15$ (2H, q, $J \mathrm{~Hz}$, $\left.\mathrm{CH}_{3} \mathrm{CH}_{2} \mathrm{O}\right), 4.25(1 \mathrm{H}, \mathrm{d}, J 8 \mathrm{~Hz}, \mathrm{PhCHN}), 4.45(1 \mathrm{H}, \mathrm{s}, \mathrm{NC}=\mathrm{CH}), 4.50(1 \mathrm{H}, \mathrm{d}, J 16 \mathrm{~Hz}$, NCHHPh), 4.85 (1H, d, J $8 \mathrm{~Hz}, \mathrm{PhCHN}), 7.30$ (15H, m, ArH), and $8.20(1 \mathrm{H}, \mathrm{br} \mathrm{s}, \mathrm{NH}) ; \delta_{\mathrm{C}} 14.7$ $\left(\mathrm{CH}_{3}\right), 46.7,57.9$ and $61.0(\mathrm{CN}), 66.8\left(\mathrm{CH}_{2} \mathrm{O}\right), 71.5\left(\mathrm{CHCO}_{2} \mathrm{Et}\right), 126.0,127.3,127.4,127.9$, 128.3, 128.5 and $128.8(\mathrm{ArCH}), 135.7,137.9$ and $140.1(\mathrm{ArC}), 162.9(\mathrm{C}=\mathrm{O})$ and $171.2(\mathrm{NCN})$; m/z 398 ( $\left.M^{+}, 23 \%\right), 307$ ( $\left.M^{+}-\mathrm{CH}_{2} \mathrm{Ph}, 10\right), 203$ (13), 181 (15), 180 (100), 179 (16), 165 (7), 130 (19) and 91 (59).

1-Benzyl-2-phenyl-4,5-dihydroimidazole (8). To 2-phenyl-4,5-dihydroimidazole (1.02 g, 7 mmol) in dry THF $\left(35 \mathrm{~cm}^{3}\right)$ stirred under nitrogen at $-20{ }^{\circ} \mathrm{C}$ was added n-butyl-lithium $\left(5.4 \mathrm{~cm}^{3}\right.$ of a 1.6M solution in hexanes, $8.5 \mathrm{mmol}$ ) followed after $30 \mathrm{~min}$ by benzyl bromide $(1.45 \mathrm{~g}, 8.5$ 
mmol). The solution was allowed to warm to room temperature overnight and quenched with methanol $\left(2 \mathrm{~cm}^{3}\right)$. The mixture was partitioned between saturated aqueous sodium bicarbonate (50 cm3) and dichloromethane $(50 \mathrm{~cm} 3)$ and the aqueous phase further extracted with dichloromethane $(2 \times 50 \mathrm{~cm} 3)$. Drying of the combined organic extracts, removal of the solvents under reduced pressure, and column chromatography of the residue $\left(\mathrm{CH}_{2} \mathrm{Cl}_{2}\right.$ :EtOH:conc. aq. $\mathrm{NH}_{3} 300: 8: 1 \mathrm{v} / \mathrm{v} / \mathrm{v}$ ) gave the title compoumd 8 as a pale yellow oil which crystallized on standing to a yellow solid (1.18 g, 72\%), m.p. $67-68{ }^{\circ} \mathrm{C}$ (Found: $M^{+}$, 236.1319. $\mathrm{C}_{16} \mathrm{H}_{16} \mathrm{~N}_{2}$ requires $M$, 236.1313); $v_{\max } / \mathrm{cm}^{-1}$ (film) 3180 (br NH), 2940, 2880, 1620, 1600, 1580, 1500, 1450 and 1400; $\delta_{\mathrm{H}} 3.40$ and 3.95 (each $2 \mathrm{H}, \mathrm{t}, J 7 \mathrm{~Hz}, \mathrm{NCH}_{2} \mathrm{CH}_{2} \mathrm{~N}$ ), $4.30\left(2 \mathrm{H}, \mathrm{s}, \mathrm{CH}_{2} \mathrm{Ph}\right), 7.40(8 \mathrm{H}, \mathrm{m}, \mathrm{ArH}$ ), and $7.70(2 \mathrm{H}, \mathrm{m}, \mathrm{ArH}) ; \delta_{\mathrm{C}} 50.6,52.6$ and $53.0\left(\mathrm{CH}_{2} \mathrm{~N}\right), 126.6,126.8,127.6,127.9,128.1$ and 129.3 (ArCH), 131.0, 137.6 (ArC) and 166.7 (NCN) ; m/z 236 ( $\left.M^{+}, 53 \%\right), 235$ (12), 117 (100), 91 (50) and 77 (16).

1-Benzyl-2-(1-ethoxycarbonyl-4-oxopentyl)-4,5-diphenyl-4,5-dihydroimidazole (9). To 1benzyl-2-(ethyoxycarbonylmethylene)-4,5-diphenyl-2,3,4,5-tetrahydroimidazole 3 (0.301 g, 0.76 mmol) in acetonitrile $\left(10 \mathrm{~cm}^{3}\right)$ was added methyl vinyl ketone $\left(75 \mathrm{~cm}^{3}, 0.91 \mathrm{mmol}\right)$ and the solution heated at reflux for $4 \mathrm{~h}$. The solvent was removed under reduced pressure and the residue purified by flash column chromatography $\left(\mathrm{CH}_{2} \mathrm{Cl}_{2}\right.$ :EtOH:conc. aq. $\left.\mathrm{NH}_{3} 400: 8: 1 \mathrm{v} / \mathrm{v} / \mathrm{v}\right)$ to give the title compound 9 as a colourless oil $\left(0.327 \mathrm{~g}\right.$, 92\%) (Found: $M^{+}, 468.2383 . \mathrm{C}_{30} \mathrm{H}_{32} \mathrm{~N}_{2} \mathrm{O}_{3}$ requires $M$, 468.2413); $v_{\max } / \mathrm{cm}^{-1}$ (film) 3080, 3050, 3000, 2950, 1735 (ester $\mathrm{C}=\mathrm{O}$ ), 1710 (ketone $\mathrm{C}=\mathrm{O}$ ), 1500, 1460, 1190, 730, and 700 ( $\mathrm{Ph}$ bend); $\delta_{\mathrm{H}}(250 \mathrm{MHz}$; mixture of diastereoisomers) 1.35 (3H, 2 x t, J 7.2 Hz, $\mathrm{CH}_{3} \mathrm{CH}_{2} \mathrm{O}$ ), 2.15 (3H, 2 x s, $\mathrm{CH}_{3} \mathrm{CO}$ ), 2.30-2.50 (2H, m, $\mathrm{CH}_{2} \mathrm{CH}_{2} \mathrm{CO}$ ), $2.73\left(2 \mathrm{H}, 2 \mathrm{x} \mathrm{dt}, J\right.$ 3.2, $\left.6.6 \mathrm{~Hz}, \mathrm{CH}_{2} \mathrm{CH}_{2} \mathrm{CO}\right), 3.71\left(1 \mathrm{H}, 2 \mathrm{x} \mathrm{t}, J 7.2 \mathrm{~Hz}, \mathrm{CHCO}_{2} \mathrm{Et}\right), 3.93$ and 3.95 (each $0.5 \mathrm{H}, \mathrm{d}, J 16.3 \mathrm{~Hz}, \mathrm{NCHHPh}$ ), 4.25 (3H, m, $\mathrm{CH}_{3} \mathrm{CH}_{2} \mathrm{O}$ and $\mathrm{PhCHN}$ ), 4.61 and 4.69 (each $0.5 \mathrm{H}, \mathrm{d}, J 16.3 \mathrm{~Hz}, \mathrm{NCHHPh}), 4.91(1 \mathrm{H}, 2 \mathrm{x} \mathrm{d}, J 7.2 \mathrm{~Hz}, \mathrm{PhCHN})$, and $7.36(15 \mathrm{H}, \mathrm{m}, \mathrm{ArH}) ; \delta_{\mathrm{C}}$ $13.7\left(\mathrm{CH}_{3}\right), 23.8,29.3,40.2,42.6,47.3,60.8,72.7,75.5,76.9\left(\mathrm{CH}_{2} \mathrm{O}\right), 125.9,126.1,126.6$, 126.8, 126.9, 127.4, 127.8, 128.0, 128.1 and $128.4(\mathrm{ArCH}), 136.1,141.0,143.8$ (ArC), 162.7 (ester $\mathrm{C}=\mathrm{O}), 169.9(\mathrm{NCN})$ and 207.2 (ketone $\mathrm{C}=\mathrm{O}) ; \mathrm{m} / \mathrm{z} 468\left(M^{+}, 9 \%\right), 399$ (12), 398 (retroMichael product, 43), 273 (19), 180 (77) and 91 (100).

Ethyl 1-[(1,2-diphenyl-2-benzylamino)ethyl]-6-methyl-1,4,5,6-tetrahydropyridine-3-carboxylate (10). To a slurry of Adams catalyst $(0.011 \mathrm{~g}, 10 \% \mathrm{w} / \mathrm{w}$, prehydrogenated for $15 \mathrm{~min})$ in ethanol $\left(5 \mathrm{~cm}^{3}\right)$ was added 1-benzyl-2-(1-ethoxycarbonyl-4-oxopentyl)-4,5-diphenyl-4,5dihydroimidazole $9(0.094 \mathrm{~g}, 0.20 \mathrm{mmol})$ in ethanol $\left(2 \mathrm{~cm}^{3}\right)$. The mixture was stirred vigorously under an atmosphere of hydrogen for $16 \mathrm{~h}$. The reaction mixture was filtered through a pad of celite (Caution: hydrogenated catalysts are pyrophoric), the solvent removed from the filtrate under reduced pressure, and the residual oil purified by column chromatography $\left(\mathrm{CH}_{2} \mathrm{Cl}_{2}\right.$ :EtOH:conc. aq. $\mathrm{NH}_{3}$ 250:8:1 v/v/v) to give the title compound 10 as a yellow oil (0.086 g, 94\%) (Found: $M^{+}, 454.2596 . \mathrm{C}_{30} \mathrm{H}_{34} \mathrm{~N}_{2} \mathrm{O}_{2}$ requires $\left.M, 454.2620\right) ; v_{\max } / \mathrm{cm}^{-1} 3400(\mathrm{NH}), 3000$, 2950, 2880, $1730(\mathrm{w}), 1660(\mathrm{C}=\mathrm{O}), 1605(\mathrm{C}=\mathrm{N}), 1540,1140,1090$ and 925; $\lambda_{\max }(\mathrm{EtOH}) / \mathrm{nm}$ 243, 305; $\delta_{\mathrm{H}}$ (mixture of rotamers) $0.70\left(1 \mathrm{H}, \mathrm{d}, J 7 \mathrm{~Hz}, \mathrm{CH}_{3} \mathrm{CHN}\right.$ rotamer a), $1.05(2 \mathrm{H}, \mathrm{d}, J 7 \mathrm{~Hz}$, $\mathrm{CH}_{3} \mathrm{CHN}$ rotamer b), $1.30\left(3 \mathrm{H}, \mathrm{t}, \mathrm{J} 7 \mathrm{~Hz}, \mathrm{CH}_{3} \mathrm{CH}_{2} \mathrm{O}\right.$ ), $1.80\left(3 \mathrm{H}, \mathrm{m}, 5-\mathrm{CH}_{2}\right.$ ), 2.50 and 2.60 (each 
$\left.1 \mathrm{H}, \mathrm{m}, 4-\mathrm{CH}_{2}\right), 3.15\left(1 \mathrm{H}, \mathrm{m}, \mathrm{CH}_{3} \mathrm{CHN}\right), 4.00(1 \mathrm{H}, \mathrm{m}, \mathrm{NHCHHPh}), 4.20$ (2H, q, J $7 \mathrm{~Hz}$, $\left.\mathrm{CH}_{3} \mathrm{CH}_{2} \mathrm{O}\right), 4.30(2 \mathrm{H}, \mathrm{m}, \mathrm{NHCHHPh}$ and $\mathrm{PhCHN}), 5.20(1 \mathrm{H}, \mathrm{m}, \mathrm{PhCHN}), 7.10(1 \mathrm{H}$, br s, $\mathrm{NCH}=\mathrm{C})$ and $7.30(15 \mathrm{H}, \mathrm{m}, \mathrm{ArH}) ; \mathrm{m} / \mathrm{z} 454\left(M^{+}\right)$.

\section{Acknowledgements}

We thank EPSRC and Glaxo Pharmaceuticals for a studentship (S.C.H.) and Drs E.W Collington and P Hallett for helpful discussion.

\section{References}

1. See: Z.-T. Huang and M.-X.Wang in The Chemistry of Enamines, ed. Z. Rappoport, Wiley Interscience, London, 1994, p 1303, for a review of 1,1-enediamines.

2. Jones, R. C. F.; Hirst, S. C. Tetrahedron Lett. 1989, 30, 5361.

3. Jones, R. C. F.; Hirst, S. C. Tetrahedron Lett. 1989, 30, 5365.

4. Jones, R. C. F.; Turner, I.; Howard, K. J. Tetrahedron Lett. 1993, 34, 6329.

5. Lifschitz; Bos, J. G. Recl. Trav. Chim. Pays-Bas 1940, 59, 173.

6. Williams, O. F.; Bailar, J. C. J. Am. Chem. Soc. 1959, 81, 4464.

7. Saigo, K.; Kubota, N.; Takebayashi, S.; Hasegawa, M. Bull. Chem. Soc. Jpn. 1986, 59, 931.

8. Jones, R. C. F.; Schofield, J. J. Chem. Soc., Perkin Trans. 1 1990, 375.

9. Anderson, M. W.; Jones, R. C. F.; Saunders, J. J. Chem. Soc. Perkin Trans. 1 1986, 1995.

10. Yamamoto, H.; Maruoka, K. J. Am. Chem. Soc. 1981, 103, 4186.

11. Duranti, E.; Balsamini, C. Synthesis 1974, 815.

12. Cf.: Anderson, M. W.; Begley, M. J.; Jones, R. C. F.; Saunders, J. J. Chem. Soc., Perkin Trans. 1 1984, 2599.

13. Barnikow, G.; Strickmann, G. Chem. Ber. 1967, 100, 1428.

14. Mangeney, P.; Alexakis, A.; Normant, J. F. Tetrahedron Lett. 1988, 29, 2677 